\title{
EDITORIAL OPEN \\ Circulating tumor cells: quintessential precision oncology presenting challenges for biology
}

npj Precision Oncology (2017)1:16; doi:10.1038/

s41698-017-0019-9

It is now well-known that cells from many types of malignant epithelial tumors delaminate and enter the circulation. These metastatic cells are known as circulating tumor cells or CTCs. CTCs have received wide attention because they offer the promise of a simple blood test to monitor the progress of cancer therapy, to aid in diagnosis and prognosis, and to define tumor evolution. Hence the liquid biopsy.

CTCs are rare cells, as few as 1 in $10^{\wedge} 9$ in a typical sample of blood. Nevertheless, it is now technically possible to isolate and characterize them based on their molecular and genetic characteristics. For the most part, CTCs are rarely detected in the peripheral blood of healthy persons; however, CTCs in the blood of cancer patients reflect disseminated disease. ${ }^{2}$

Because of their epithelial nature, CTCs are usually detected first by depleting hematopoietic cells by CD45 (common leukocyte antigen) conjugated magnetic beads, followed by attaching fluorescence conjugated antibodies to the epithelial cell adhesion molecule, EpCAM, with further analysis for cytokeratins such as CK19, or by pan-cytokeratin imunoreactivity. ${ }^{3}$ Novel automated instrumentation such as the FDA cleared CellSearch System (Janssen Diagnostics, LLC, Raritan, NJ (formerly Veridex)) and the CytoTrack (CytoTrack ApS, Lyngby, Denmark) are used to collect and to analyze the cells. ${ }^{4}$ Other devices have been reported to aid isolation and characterization of CTCs. Even the downstream technology is promising, with the ability to perform reliably RNA-sequencing and DNA-sequencing on the single cells. Examples of several published instruments for CTC analysis with advantages and disadvantages are summarized in Table 1.

However, despite the technological advances in identifying and characterizing CTCs, there are still significant biological challenges.

The first challenge quite simply, is sample size: as few as $1 / 10^{\wedge} 9$ cells per $7 \mathrm{ml}$ sample of blood. Although the results of sequencing undeniably inform the nature of the cell in question, what does a single gene expression profile (or five or even ten), tell us about the biology a tumor or its metastases? Indeed EpCam expression can vary in CTCs, and amplification prior to sequencing RNA or DNA from single cells can induce bias. The former problem has been addressed by Sakurai et al. ${ }^{5}$ who targeted the CTCS a conditionally replicating adenovirus containing a green fluorescent protein (rAd-GFP) with human telomerase reverse transcriptase (hTERT). The rAd-GFP construct could thus proliferate in the hTERT-positive CTCs such that they expressed GFP. This aspect enabled an enrichment of CTCs regardless of EpCAM expression. With regard to the latter problem, it should also be possible to induce pluripotent stem cells from individual CTCs enabling clonal

\begin{tabular}{|c|c|c|c|c|c|}
\hline Screen Cell & $\begin{array}{l}\text { Cell size: filtration of CTCs } \\
\text { with the Screen Cell device }\end{array}$ & $\begin{array}{l}\text { Captured cells are ready for cell } \\
\text { culture, immunostaining or } \\
\text { molecular biology }\end{array}$ & $\begin{array}{l}\text { Advantage-CTCs are available } \\
\text { for live cell in vitro methods }\end{array}$ & $\begin{array}{l}\text { Potential for in vitro } \\
\text { functional analysis }\end{array}$ & $\begin{array}{l}\text { Desitter } \\
\text { et al. }{ }^{11}\end{array}$ \\
\hline $\begin{array}{l}\text { Viatar CTC } \\
\text { Solutions }\end{array}$ & $\begin{array}{l}\text { Oncopheresis (dialysis) CTCs } \\
\text { are the least deformable } \\
\text { peripheral blood cells }\end{array}$ & $\begin{array}{l}\text { Downstream detection of } \\
\text { immunoreactive cells }\end{array}$ & $\begin{array}{l}\text { Advantage-can collect more } \\
\text { live cells than other methods } \\
\text { Disadvantage-requires } 4 \mathrm{~h} \text { of } \\
\text { machine dialysis }\end{array}$ & $\begin{array}{l}\text { Undergoing human } \\
\text { clinical trials, } \\
\text { potential removal of } \\
\text { metastatic cells }\end{array}$ & $\begin{array}{l}\text { Coumans } \\
\text { et al. }{ }^{12}\end{array}$ \\
\hline $\begin{array}{l}\text { Micro-Hall } \\
\text { detector }\end{array}$ & $\begin{array}{l}\text { Micro fluidics together with } \\
\text { immunomagentic detection } \\
\text { of cancer stem cell } \\
\text { therapeutic targets }\end{array}$ & $\begin{array}{l}\text { Downstream profiling of single } \\
\text { cells }\end{array}$ & $\begin{array}{l}\text { Advantage-high throughput, } \\
\text { high sensitivity }\end{array}$ & $\begin{array}{l}\sim 50 \text { times more } \\
\text { sensitive than } \\
\text { CellSearch }\end{array}$ & $\begin{array}{l}\text { Issadore } \\
\text { et al. }{ }^{14}\end{array}$ \\
\hline
\end{tabular}

Received: 23 January 2017 Revised: 27 March 2017 Accepted: 13 April 2017

Published online: 08 May 2017 
amplification of the cells and less bias upon sequencing. Moreover, the number of CTCs approximates the number of fetal cells persisting in the blood of female patients. ${ }^{6}$ Surely it is important to control for fetal chimerism in breast or ovarian cancer patients? Perhaps by inclusion of Y-Fluorescence In Situ Hybridization or other tissue-type markers? ${ }^{7}$

A second major challenge to biologists is insufficient knowledge of cytokeratin positive cells present in the blood of "healthy" individuals. ${ }^{8}$ Although often attributed to occult malignancy, there are other tantalizing biological questions waiting to be answered such as whether these rare cells might reflect an undiscovered function of normal epithelial cells, or even an undiscovered circulating epithelial progenitor. A related challenge is determining the significance of circulating epithelial cells in non-cancerous inflammatory disorders. ${ }^{9}$ Very little is known about this. Such knowledge could illuminate epithelial biology in general and inform inflammatory processes in particular. Moreover, we would conjecture that a comparison of the quantification of healthy-cell quantitative variable measures with corresponding disease-cell variable measures would also be informative.

A third challenge is the heterogeneity within the population of CTCs; how does one detect their possible transitions between epithelial and mesenchymal profiles. Here, additional markers for EMT such as twist, snail, and slug could be added. ${ }^{8}$ It is possible that mouse models of cellular lineage tracing could be applied to inform these cellular transitions during tumor evolution.

In summary, recent advances in detection and analysis of CTCS offer the promise of a liquid biopsy, laying the foundation for discovery of new tumor biomarkers and new knowledge on circulating epithelial cells in general. However, there are significant quantitative and biological challenges in this rapidly evolving field. Solutions to these challenges are as difficult as they are obvious, but are surely worth the effort.

Rebecca J. Morris ${ }^{1}$

${ }^{1}$ The Hormel Institute, University of Minnesota, Austin, USA Correspondence: Rebecca J. Morris (rmorris@hi.umn.edu)

\section{COMPETING INTERESTS}

The authors declare no competing financial interests.

\section{REFERENCES}

1. Alix-Panabieres, C. \& Pantel, K. Clinical applications of circulating tumor cells and circulating tumor DNA as liquid biopsy. Cancer Discov 6, 1-13 (2016).

2. Fehm, T., Sagalowsky, A., Clifford, E., Beitsch, P., Saboorian, H., Euhus, D., Meng, S., Morrison, L., Tucker, T., Lane, N., Ghadimi, B. M., Heselmeyer-Haddad, K., Ried, T., Rao, C. \& Uhr, J. Cytogenetic evidence that circulating epithelial cells in patients with carcinoma are malignant. Clin. Cancer Res. 8, 2073-2084 (2002).
3. Crowley, E., DiNicolantonio, F., Loupakis, F. \& Bardelli, A. Liquid biopsy: monitoring cancer genetics in the blood. Nat. Rev. Clin. Oncol. 10, 472-484 (2013).

4. Hillig, T., Horn, P., Nygaard, A. B., Haugaard, S., Nejlund, S., Brandslund, I. \& Soletormos, G. In vitro detection of circulating tumor cells compared by the CytoTrack and CellSearch methods. Tumor Biol. 36, 4597-4601 (2015).

5. Sakurai, F., Narii, N., Tomita, K., Togo, S., Takahashi, K., Machitani, M., Tachibana, M., Ouchi, M., Katagiri, N., Urata, Y., Fujiwara, T. \& Mizuguchi, H. Efficient detection of human circulating tumor cells without significant production of false-positive cells by a novel conditionally replicating adenovirus. Mol. Ther. Methods Clin. Dev. 3, 16001 (2016).

6. Goldberg, J. D. Fetal cells in maternal circulation: progress in analysis of a rare event. Am. J. Hum. Genet. 61, 806-809 (1997).

7. Schlutter, J. M., Kirkegaard, I., Petersen, O. B., Larsen, N., Christensen, B., Hougaard, D. M., Kelvraa, S. \& Uldbjerg, N. Fetal gender and several cytokines are associated with the number of fetal cells in maternal blood-an observational study. PLoS ONE 9(9), e106934 (2014).

8. Lustberg, M. B., Balasubramanian, P., Miller, B., Garcia-Villa, A., Deighan, C., Wu, Y., Berger, M., Ramaswamy, B., Macrae, E. R., Wesolowski, R., Layman, R. M., Mrozek, E., Pan, X., Summers, T. A., Shapiro, C. L. \& Chalmers, J. J. Heterogeneous atypical cell populations are present in blood of metastatic breast cancer patients. Breast Cancer Res. 16, R23 (2014).

9. Pantel, K., Daneve, E., Nocca, D., Coffy, A., Vendreff, J. P., Maudelonde, T., Rethdorf, S. \& Alix-Panabieres, C. Circulating epithelial cells in patients with benign colon disease. Clin. Chem. 58, 936-940 (2012).

10. Hillig, T., Nygaagard, A. B., Nekiunaite, L., Klingelhofer, J. \& Soletormos, G. In vitro validation of an ultra-sensitive scanning fluorence microscope for analysis of circulating tumor cells. Acta Pathol. Microbiol. Immunol. Scand. 122, 545-551 (2014).

11. Desitter, I., Guerrouahen, B. S., Benali-Furet, N., Weschler, J., Janne, P. A., Kuang, Y., Yanagita, M., Lang, L., Berkowitz, J. A., Distel, R. J. \& Cayre, Y. A new device for rapid isolation by size and characterization of rare circulating tumor cells. Anticancer Res. 31, 427-442 (2011).

12. Coumans, F., Ligthart, S. \& Tersteppen, L. Interpretation of changes in circulating tumor cell counts. Transl. Oncol. 5, 486-491 (2012).

13. Obrien, C. M., Rood, K. D., DeSouza, T., Sengupta, S., Gupta, S. K., Mosley, B. S., Goldschmidt, B. S., Sharma, N. \& Viator, J. A. Isolation of circulating tumor cells using photoacoustic flowmetry and two phase flow. J. Biomed. Opt. 17, 061221 (2012).

14. Issadore, D., Chung, J., Shao, H., Liong, M., Ghazani, A. A., Castro, C. M. \& Lee, H. Ultrasensitive clinical enumeration of rare cells ex vivo using a micro-hall detector. Sci. Transl. Med. 4, 141 ra92 (2012).

\footnotetext{
Open Access This article is licensed under a Creative Commons adaptation, distribution and reproduction in any medium or format, as long as you give appropriate credit to the original author(s) and the source, provide a link to the Creative Commons license, and indicate if changes were made. The images or other third party material in this article are included in the article's Creative Commons license, unless indicated otherwise in a credit line to the material. If material is not included in the article's Creative Commons license and your intended use is not permitted by statutory regulation or exceeds the permitted use, you will need to obtain permission directly from the copyright holder. To view a copy of this license, visit http://creativecommons. org/licenses/by/4.0/.
}

(c) The Author(s) 2017 